Jurnal Luxnos Vol. 4, No. 2, Edisi Agustus - Desember 2018

\title{
Hubungan Peranan Guru Pendidikan Agama Kristen Dengan Pertumbuhan Iman Peserta Didik
}

\author{
Abraham Tefbana \\ Sekolah Tinggi Teologi Pelita Dunia Tangerang \\ abrahamtefbana@gmail.com
}

\begin{abstract}
In this article the author is concerned about the relationship between the role of Christian Religious Education teachers and the growth of the faith of students, because Christian Religious Education teachers have special competencies that can be emulated by students.
\end{abstract}

Key words: Teacher, Christian Religious Education, Faith Growth

\begin{abstract}
Abstrak: Dalam artikel ini penulis konsen membahas tentang hubungan peranan guru Pendidikan Agama Kristen dengan Pertumbuhan iman peserta didik, karena guru Pendidikan Agama Kristen memiliki kompetensi khusus yang dapat diteladani oleh para peserta didik.
\end{abstract}

Kata-kata kunci: Guru, Pendidikan Agama Kristen, Pertumbuhan Iman

\section{Pendahuluan}

Sebelum membahas tentang peranan guru Pendidikan Agama Kristen dalam membina pertumbuhan iman peserta didik, maka sangat perlu untuk terlebih dahulu untuk memahami tentang pengertian dari istilah pembinaan dan pembina.

Kamus Besar Bahasa Indonesia (KBBI) mendefenisikan bahwa; "Pembinaan berarti usaha, tindakan dan kegiatan yang dilakukan secara berdaya guna dan berhasil guna untuk memperoleh hasil yang lebih baik."1 Istilah Pembina didefiniskan bahwa; "Pembinaan berasal dari kata "bina", berarti guru Pendididikan Agama Kristen membangun, memperbaiki. Suatu usaha yang dilakukan oleh guru Pendididikan Agama Kristen untuk membangun atau memperbaiki, mengembangkan serta memperbaharui perbuatan dan sikap kearah yang lebih dewasa."2 Sedangkan istilah membimbing didefenisikan bahwa; "Membimbing berasal dari kata dasar 'bimbing' yang berarti memberi petunjuk; mengasuh; terutama orangtualah yang berkewajiiban membawa anak-anaknya ke jalan yang benar."3

\footnotetext{
1 Tim penyusun KBBI, Jakarta: Balai Pustaka, 2002, hlm. 152.

2 Ibid, hlm. 152.

3 Ibid, hlm. 232
} 
Bimbingan berarti guru Pendididikan Agama Kristen memberi petunjuk atau penjelasan, berarti cara mengajarkan sesuatu, tuntunan, pimpinan. Pengertian pembina berarti guru Pendididikan Agama Kristen yang berperan memberi petunjuk, untuk membangun, memperbaiki, mengembangkan dan memperbaharui karakter seseorang menjadi lebih baik. Jika dibahas dalam perspektif iman Kristen, maka pembina adalah guru Pendididikan Agama Kristen yang berusaha untuk memberi pengetahuan firman Tuhan dalam rangka membangun iman dan karakter seseorang kepada Allah di dalam Tuhan Yesus Kristus.

A. J. Jones menyatakan bahwa: "Bimbingan merupakan pemberian bantuan oleh seseorang kepada orang lain dalam menentukan pilihan penyesuaian dan pemecahan permasalahan. Bimbingan bertujuan membantu sipenerima agar bertambah kemampuan bertanggung jawab atas dirinya. Tekanan disini diberikan pada bantuan, sehingga orang yang dibimbing lebih berperan dalam menentukan arah bantuan itu". ${ }^{4}$ Guru Pendididikan Agama Kristen berperan memberi bantuan kepada peserta didik untuk mampu memecahkan masalahnya dan bertanggungjawab atas dirinya untuk sanggup menentukan pilihannya. Tujuan pembinaan pertumbuhan iman peserta didik, agar mampu bertanggung jawab terhadap dirinya dalam menghadapi segala masalah dalam hidupnya dengan mengandalkan Tuhan.

L. D. Crow dan A. Crow berpendapat bahwa; "Bantuan atau pendampingan dengan tambahan bahwa bimbingan harus memperoleh latihan khusus agar pemberian bantuannya bertanggung jawab, karena erat hubungannya dengan perubahan hidup dan nasib seseorang." ${ }^{5}$ Sebagai pembina pertumbuhan iman peserta didik, guru PAK harus memperoleh pelatihan atau pengetahuan khusus tentang metode pembinaan iman peserta didik, karena bertanggungjawab untuk bantuan setiap peserta didik yang tidak mampu mengatasi masalahnya kehidupan yang dijalaninya sendiri.

Tujuan diadakannya pembinaan bagi seorang peserta didik untuk menuntun dan meningkatkan kemampuannya agar mampu memahami kepribadian sebagai peserta didik, mengenal lingkungan secara objektif, dan menerima keadaan dilingkungannya itu dengan apa adanya. Lingkungan peserta didik yang dimaksud itu adalah lingkungan keluarganya, sekolahnya dan lingkungan masyarakat tempat berdomidili. Setiap peserta didik harus dapat menyesuaikan diri dengan lingkungannya, dan mampu memanfaatkan lingkungan sebaik mungkin untuk pertumbuhan imannya dan masa depannya. Selain pembina peserta didik untuk pertumbuhan imannya, juga menuntunnya agar mampu merencanakan masa depannya. Guru Pendididikan Agama Kristen memberi bimbingan kepada peserta didik untuk

${ }^{4}$ Singgih D. Gunarsa, dan Y. Singgih D. Gunarsa, Psikologi untuk Membimbing, (Jakarta: BPK Gunung Mulia 2007), hlm. 11.

5 Ibid. hlm. 12 
meraih cita-citanya, maka disiplin ilmunya juga harus ada korelasinya dengan karier yang dicita-citakannya.

Prayitno dan Erman Amti menyatakan bahwa: Bimbingan adalah bagian dari proses pendidikan yang literatur dan sistematik guna membantu pertumbuhan anak muda atas kekuatannya dalam menentukan dan mengarahkan hidupnya sendiri. ${ }^{6}$ Peran guru Pendididikan Agama Kristen penting, karena lewat proses pembimbingan yang baik bagi seorang peserta didik, akan membantunya bertumbuh imannya dan memampukannya untuk memperoleh pengetahuan yang benar dan teratur mencapai cita-citanya untuk pribadinya, keluarganya, dan masyarakat lingkungannya.

Bimbingan sebagai suatu proses pemberian bantuan kepada setiap individu peserta didik yang dilakukan secara bertahap dan berkesinambungan agar dapat memahami dirinya sendiri, sehingga mampu bertindak secara wajar, sesuai firman Tuhan dilingkungan keluarga, sekolah dan masyarakat pada umumnya. Guru Pendididikan Agama Kristen dalam peran sebagai pembimbing membantu peserta didik untuk bertumbuh imannya dan mencapai perkembangan dirinya sendiri secara optimal sebagai makhluk social yang membutuhkan orang lain untuk pertumbuhan dan perkembangan terutama imannya. Karena melalui pembimbingan, peserta didik akan bertumbuh imannya dan dapat mencapai cita-citanya yang dapat membangun dirinya sendiri, keluarga dan kepada masyarakat pada umumnya.

Hodari Nawawi mengatakan bahwa: Bimbingan pendidikan adalah pertolongan yang diberikan terhadap orang atau peserta didik yang mengalami kesulitan belajar dan kesukaran-kesukaran lain yang timbul dalam interaksinya dengan pembimbing termasuk guru dan orangtua. ${ }^{7}$ Idielnya setiap peserta didik perlu pembimbingan dari guru Pendididikan Agama Kristen untuk membimbingannya dalam pertumbuhan imannya, memberinya motivasi dalam mencapai cita-citanya, memberinya semangat dalam mengatasi berbagai masalahnya sendiri termasuk masalah belajar. Jadi bimbingan merupakan pertolongan yang diberikan kepada peserta didik yang menghadapi kesukaran dalam pertumbuhan imannya, sekolah yang berhubungan dengan belajar, keluarga, pergaulannya di sekolah dan dilingkungan masyarakat.

Bimbingan pribadi adalah pertolongan yang diberikan pada orangtua atau peserta didik yang mengalami kesukaran berupa konflik-konflik, baik yang berasal dari dalam dirinya antara lain temannya, anggota keluarga,

6 Prayitno, dan Erman Amti, DAsar-dasar Bimbingan dan Konseling, (Jakarta: Rineka Cipta, 2004), hlm. 94

7 Hodari Nawawi, Administrasi dan Organisasi Bimbingan dan Penyuluhan, (Pontianak: Grahlia Indonesia, 1986), hlm. 26 
terutama orang tuanya. ${ }^{8}$ Seorang peserta didik perlu bimbingan dari guru Pendididikan Agama Kristen untuk menolongnya menghadapi dan menyelesaikan konflik-konflik yang terjadi antara dirinya dengan orangtuanya atau dengan teman-teman sebayanya baik di sekolah dan lingkungan masyarakat bahkan di gerejanya. Tujuannya agar terciptanya keharmonisan baik di dalam keluarga yaitu dengan orangtuanya, dan dengan teman-teman sebayanya di sekolah, lingkungan dan gereja.

Soejipto, dan Raflis Kosasi memberi rumusan mengenai bimbingan bahwa; Bimbingan adalah bantuan atau pertolongan yang diberikan kepada individu atau sekumpulan individu dalam menghindari atau mengatasi kesulitan-kesulitan di dalam kehidupannya, agar individu dapat mencapai kesejahteraan hidupnya. ${ }^{9}$ Dalam pengertian bahwa guru Pendididikan Agama Kristen dalam peran sebagai pembina pertumbuhan iman peserta didik di sekolah, tapi juga di gereja dan juga dilingkungan masyarakat. Tujuannya agar menolong peserta didik agar betumbuh imannya dan untuk mampu menyelesaikan kesulitan-kesulitan atau konflik-konflik dalam belajar, dalam pergaulan, dan komunitas-komunitas di masyarakat.

Dari berbagai pengertian tentang pembinaan, dapat disimpulkan bahwa pembinaan merupakan suatu proses yang berkesinambungan dari guru Pendididikan Agama Kristen dengan peserta didik, dengan membantu mengarahkan dan mengembangkan diri peserta didik secara optimal sesuai kemampuan atau potensinya. Diharapkan agar melalui proses pembinaan peserta didik mampu keluar dari setiap permasalahan kehidupannya secara individu dengan berorientasi kepada Tuhan Yesus Kristus sebagai bukti kedewasaan imannya.

Dalam proses pembinaan pertumbuhan iman peserta didik, guru Pendididikan Agama Kristen hadir untuk memberi motivasi, memberi bimbingan, dan memberi rasa nyaman, agar peserta didik mengalami pertumbuhan iman dengan maksimal. Dalam hal ini, guru Pendididikan Agama Kristen bertanggung jawab untuk mengetahui pertumbuhan iman peserta didik dan perkembangannya secara komprehensif dalam kehidupannya, agar memberi pembinaan yang dibutuhkan.

Sehubungan dengan peranan guru Pendididikan Agama Kristen, maka Slameto menyampaikan tiga point tentang tugas guru Pendididikan Agama Kristen sebagai pembina iman peserta didik sebagai berikut; (1). Mendidik dengan titik berat memberikan arahan dan motivasi pencapaian tujuan baik jangka pendek maupun jangka panjang. (2). Memberi fasilitas tercapai tujuan melalui pengalaman belajar yang memadai. (3). Membantu perkembangan

8 Ibid, hlm.26.

9 Soejipto, dan Raflis Kosasi, Profesi Keguruan, (Jakarta: Rineka Cipta, 1999), hlm. 
aspek-aspek pribadi seperti sikap, nilai-nilai, dan penyesuaian diri. ${ }^{10}$ Dalam proses pembelajaran guru Pendidikan Agama Kristen, tidak hanya sebatas sebagai sumber informasi pengetahuan firman Tuhan, tapi bertanggung jawab bagi pertumbuhan iman peserta didik. Dengan demikian, guru Pendidikan Agama Kristen dalam bertindak sebagai pembina iman peserta didik yang harus mampu menciptakan kondisi pembelajaran yang dapat merangsang para peserta didik untuk mempelajari firman Tuhan. Guru Pendididikan Agama Kristen sebagai pembina iman peserta didik memfokuskan dirinya pada pertumbuhan iman peserta didik. Dalam proses pembinaan pertumbuhan iman peserta didik, guru Pendididikan Agama Kristen tidak hanya mengajarkan pengetahuan tentang firman Tuhan, tetapi lebih pada tanggung jawabnya membina pertumbuhan iman peserta didik. Guru Pendididikan Agama Kristen harus mampu menciptakan proses pembinaan pertumbuhan iman peserta didik yang menyenangkan sehingga dapat merangsang peserta didik untuk belajar secara aktif dan dinamis.

Guru sebagai pengajar, pemimpin kelas, pembimbing, pengatur lingkungan, partisipan, ekspeditor, perencana, supervisor, motivator, dan konselor. ${ }^{11}$ Guru Pendididikan Agama Kristen dalam hubungan dengan pembinaan pertumbuhan iman peserta didik, memiliki peranan yang sangat penting dalam menentukan kualitas pembinaannya bagi peserta didik. Karena guru Pendididikan Agama Kristen selain sebagai pengajar, juga berperan sebagai pemimpin, pembimbing, pengatur lingkungan, partisipan, ekspeditor, perencana, supervisor, motivator, inspirator dan konselor bagi peserta didik binaan haruslah tetap berusaha menciptakan kondisi pembinaan yang efektif, efesien dan nyaman. Dengan demikian guru Pendididikan Agama Kristen sebagai pembina iman peserta didik, harus memiliki kompetensi dalam pengetahuan firman Tuhan dan menjadi figur yang dapat diteladani karena memiliki karakter Tuhan Yesus Kristus.

Stephen Tong menyatakan, bahwa; Seorang guru agama adalah seorang yang di dalam dirinya sendiri memiliki keyakinan kepercayaan yang teguh, ibadah yang beres, memiliki sifat moral dan hidup kesucian, kebajikan sesuai dengan agamanya, sehigga ia mengerjakan segala sesuatu dengan bertanggung jawab untuk kekekalan. ${ }^{12}$ Guru Pendididikan Agama Kristen sebagai pembina pertumbuhan iman peserta didik haruslah tidak hanya mengajarkan firman Tuhan, tetapi juga harus menyerahkan seluruh hidupnya untuk Tuhan Yesus Kristus bagi kemuliaan-Nya. Guru Pendididikan Agama Kristen sebagai pembina iman peserta didik tidak boleh merasa puas

10 Slameto, Belajar dan Faktor-faktor yang Mempengaruhinya, (Jakarta: Rineka Cipta, 2003), hlm. 97

11 Moh. Uzer Usman, Menjadi Guru Profesional, (Bandung: PT. Remaja Rosdakarya, 2008), hlm. 9

12 Stephen Tong, Arsitek Jiwa II, (Surabaya: Momentum, 2008), hlm. 8-9 
sebelum para peserta didik binaannya dewasa imannya dalam melayani Tuhan dan pekerjaan-Nya. Guru Pendididikan Agama Kristen dituntut, untuk mempunyai hubungan pribadi yang harmonis dengan Tuhan Yesus Kristus, serta dalam hidupnya nampak atau mencerminkan kehidupan dan karakter Tuhan Yesus Kristus.

\section{Metode Penelitian}

Pada penelitian ini, penulis atau peneliti menggunakan pendekatan atau metode kualitatif untuk memperoleh data yang valid guna membangun sebuah teori yang berkaitan dengan tema atau pokok penelitian. Metode kualitatif yang dimaksud adalah mengkaji dan mengelaborasi setiap sumber, informasi dan data-data yang diperoleh dari pustaka.

\section{Hasil dan Pembahasan}

Peranan guru PAK dengan pembinaan pertumbuhan iman peserta didik sebagai:

1. Guru PAK Sebagai Pembimbing

Guru Pendididikan Agama Kristen sebagai pembina harus memiliki kompetensi untuk memimpin, penuntun, menggembalakan para peserta didik yang dibinanya, agar bertumbuh imannya kepada Allah di dalam Tuhan Yesus Kristus.

Thoifuri mengatakan bahwa; Membimbing berarti mengarahkan kepada individu, peserta didik mana yang mempunyai kemampuan kurang, sedang dan tinggi. ${ }^{13}$ Dari sisi pendidikan, setiap peserta didik mempunyai kemampuan intelektual yang berbeda-beda. Ada yang kemampuan inteleknya rendah, sedang dan tinggi. Pada sisi ini guru Pendididikan Agama Kristen berperan untuk membimbing para peserta didik yang prestasi belajarnya menurun, agar meningkatkan prestasi belajarnya dengan tetap mengandalkan Tuhan dalam hidupnya.

B. S. Sidjabat menyatakan bahwa; Gurulah yang membimbing peserta didiknya untuk belajar mengenal memahami dan menghadapi dunia tempat ia berada. ${ }^{14}$ Guru Pendididikan Agama Kristen sebagai pembina iman peserta didik agar juga bertumbuh dalam ilmu pengetahuan, berkarya, dan sosial budaya. Dalam membina pertumbuhan iman peserta didik, guru Pendididikan Agama Kristen sebagai perantara berperan untuk berkomunikasi dengan peserta didik agar dapat memahami penerapan kedewasaan imannya dalam belajar, berkarya dan bersosialisasi.

Guru Pendididikan Agama Kristen berperan sebagai pembina iman peserta didik, terus berupaya agar para peserta didik binaannya berimannya

13 Thoifuri, Menjadi Guru Inisiator, (Semarang: Rasail Media Group, 2008), hlm. 47

14 B. S. Sidjabat, Menjadi Guru Profesional: Sebuah Perspektif Kristiani, (Bandung: Yayasan Kalam Hidup, 2000), hlm. 29 
kepada Allah, agar dirinya dimampukan dalam belajar dan mencapai citacitanya. Guru Pendididikan Agama Kristen harus mengusahakan agar peserta didik dapat memahami bahwa, dirinya adalah milik Kristus, Bait Allah tempat Roh Allah berdiam, sehingga terus mengembangkan karakternya agar menjadi serupa dengan hidup dan karakter Yesus Kristus. Jadi Guru Pendididikan Agama Kristen harus terus berupaya mengembangkan karakter Yesus Kristus dalam pribadi setiap peserta didik binaan, agar memahami tujuan hidupnya yaitu untuk kemuliaan Allah di dalam Tuhan Yesus Kristus.

E. Mulyasa menyatakan bahwa; Sebagai pembimbing, Pembina rohani harus merumuskan tujuan secara jelas, menetapkan waktu perjalanan, menetapkan perjalanan yang harus ditempuh, menggunakan petunjuk perjalanan serta menilai kelancaranya sesuai dengan kebutuhan dan kemampuan peserta didik. ${ }^{15}$ Dalam peran sebagai pembina pertumbuhan iman peserta didik, guru Pendididikan Agama Kristen harus menetapkan lamanya waktu pembinaan, metode pembinaan, dan materi-materi pembinaan dengan melihat kemampuan para peserta didik. Guru Pendididikan Agama Kristen harus mampu mempengaruhi para peserta didik melalui sikap dan keteladanan dari setiap aspek kehidupannya.

Peranan guru sebagai pembimbing lebih di utamakan karena kehadiran guru disekolah adalah untuk membimbing remaja agar menjadi manusia dewasa susila yang cakap. ${ }^{16}$ Dalam hubungannya dengan pembinaan iman peserta didik, maka lewat berbagai pembinaan dari guru Pendididikan Agama Kristen, para peserta didik dituntun untuk menjadi dewasa dan mandiri agar tidak bergantung kepada orangtua, guru dan pembina imannya.

\section{Guru PAK Kristen Sebagai Konselor}

Dalam peranan sebagai pembina iman peserta didik, guru Pendididikan Agama Kristen bertindak sebagai konselor. Artinya guru Pendididikan Agama Kristen berfungsi membimbing dan menunjukkan jalan keluar bagi para peserta didik yang mengalami berbagai kesulitan atau masalah di dalam belajar dan pergaulannya baik di sekolah, gereja dan lingkungan masyarakatnya.

Syaiful Bahri Djamarah, menyatakan bahwa: Kemudian jelas bahwa menjadi guru pada tingkat manapun berarti menjadi penasehat dalam menjadi orang kepercayaan. Kegiatan pembelajaranpun meletakkannya pada posisi tersebut. ${ }^{17}$ Peranan guru Pendididikan Agama Kristen sebagai

15 E. Mulyasa, menjadi guru profesional, menciptakan pembelajaran kreatif dan menyenangkan, (Bandung: Remaja rosdakarya, 2008), hlm. 41

16 Syaiful Bahri Djamarah, Guru dan Nara didik, (Jakarta: Rineka, 2000), hlm. 34

17 Ibid. Hlm. 34 
penasehat para peserta didik agar ketika berhadapan dengan kesulitan hidupnya, harus mampu membuat keputusan yang Alkitabiah dengan tuntunan Roh Kudus, sesuai bimbingan pembina iman.

Guru Pendididikan Agama Kristen, memberi nasehat kepada setiap peserta didik agar menemukan dirinya sendiri di dalam Tuhan Yesus Kristus, sebagai pribadi yang unik dan sangat berharga di mata Allah dan menjadi saksi-Nya yang memuliakan Tuhan dalam hidupnya bagi teman-teman sebayanya. Remaja yang menemukan dirinya di dalam Allah akan terus berupaya untuk hidup mengasihi dan memiliki karakter Tuhan Yesus Kristus di dalam hidupnya. Peserta didik yang memiliki pemahaman iman yang sedemikian, ketika menghadapi masalah tidak akan menyalahkan orang lain atau dirinya sendiri.

Tujuan guru Pendididikan Agama Kristen berperan sebagai konselor bagi para peserta didik, supaya dalam melakukan segala sesuatu yang berhubungan dengan keluarga, sekolah, gereja, dan lingkungannya harus selalu berpusat kepada Tuhan Yesus Kristus, sebagai sumber hidupnya. Maka haruslah guru Pendididikan Agama Kristen yang berperan sebagai konselor peserta didik dengan memberikan waktu, tenaga dan bahkan seluruh totalitas hidupnya dalam menuntun dan mengarahkan para peserta didik binaannya kearah kedewasaan iman kepada Allah di dalam Tuhan Yesus Kristus.

\section{Guru PAK Sebagai Fasilitator.}

Guru Pendididikan Agama Kristen sebagai fasilitator memiliki bertanggungjawab untuk memfasilitasi para peserta didik binaannya dalam urusan dengan keluarga, sekolah, gereja dan bahkan masyarakat dilingkungan remaja. B. S. Sidjabat menyatakan: Dengan peranan ini guru terpanggil untuk memahami kebutuhan berbagai peserta didik dalam proses belajar. Sebagai fasilitator guru mempersiapkan berbagai sarana yang menunjang kegiatan mengajar. ${ }^{18}$ Sebagai fasilitator maka guru Pendididikan Agama Kristen, berperan memfasilitasi peserta didik dalam menyelesaikan berbagai problemanya dengan orangtua dan keluarganya, teman sebayanya di sekolah, di gereja atau bahkan masyarakat dilingkungannya. Oleh karena itu guru Pendididikan Agama Kristen dalam peran sebagai fasilitator perlu untuk mengetahui dan bahkan memahami kebutuhan-kebutuhan setiap peserta didik binaannya itu, agar dapat mengalokasikan waktu, tenaga, pikiran, materi dan berbagai kebutuhan lain dalam peran sebagai fasilitator bagi para peserta didik binaannya.

Dalam konteks pergaulan, maka tindakan nyata guru Pendididikan Agama Kristen, sebagai fasilitator adalah memfasilitasi peserta didik untuk

18 B. S. Sidjabat, Op. Cit. hlm. 41 
menyelesaikan masalah dirinya dengan teman sebayanya dalam pergaulan baik itu di sekolah, gereja ataupun itu dilingkungan masyarakatnya. Dalam konteks iman Kristen, maka tindakan nyata guru Pendididikan Agama Kristen, sebagai fasilitator adalah memfasilitasi para peserta didik untuk menerima Tuhan Yesus Kristus menjadi Tuhan dan Juruselamat pribadi dengan mengajarkan kebenaran Firman Tuhan yang Alkitabiah. Selanjutnya berdasarkan pengetahuan firman Tuhan yang Alkitabah, yang berdampak pada pertumbuhan imannya, maka peserta didik menjadi dewasa di dalam Tuhan, dan akan mampu menghadapi dan menyelesaikan masalahnya sendiri baik itu dikeluarganya, di gerejanya, di sekolahnya dan dilingkungan masyarakatnya.

Sebagai seorang fasilitator seorang guru Pendididikan Agama Kristen harus mampu menjadi penengah agar para peserta didik binaannya bertumbuh imannya dan menjadi dewasa di dalam Tuhan Yesus Kristus, serta mencapai cita-citanya agar hidupnya menjadi kesaksian bagi Tuhan dan menjadi berkat bagi orang lain. Keteladaan hidup guru Pendididikan Agama Kristen sebagai seorang fasilitator akan menumbuhkan benih-benih kehidupan yang akan menjadi fasilitator dari para peserta didik binaan, untuk melanjutkan peran sebagai fasilitator dalam hidup dan pelayanannya.

\section{Guru PAK Sebagai Motivator.}

Seorang guru Pendididikan Agama Kristen, yang berperan sebagai motivator dalam tindakan nyatanya memberi motivasi kepada para peserta didik binaannya seperti belajar firman Tuhan agar bertumbuh imannya, memotivasi peserta didik binaannya agar tekun dalam belajar agar berprestasi dan mencapai cita-citanya dan menghormati orangtuanya.

B. S. Sidjabat menyatakan bahwa; Karena watak dan sifat manusia membutuhkan dorongan, desakan, rangsanggan dari sesamanya."19 Pada dasarnya manusia makluk sosial yang membutuhkan motivasi atau rangsangan dari sesamanya. Selanjutnya Sijabat mengatakan; Sifat perbuatan belajar itu sendiri sebagai proses dan upaya apa adanya, sangat membutuhkan "suntikan-suntikan", kita tahu bahwa dorongan dapat terjadi melalui tantangan ataupun hukuman, serta melalui pujian dan penghargaan. ${ }^{20}$ Pada dasarnya manusia butuh sesamanya untuk mengembangkan dirinya. Di dalam proses pembelajaran manusia sangat membutuhkan motivasi dari sesamanya, agar dapat mencapai tujuannya atau sukses dalam usahanya. Karena rasul Paulus mengatakan kepada jemaat Tuhan di kota Roma bahwa; "Kita yang kuat wajib menanggung kelemahan orang yang tidak kuat dan jangan kita mencari kesenangan kita sendiri,

19 B. S. Sidjabat, Op. Cit. hlm. 110

${ }^{20}$ B. S. Sidjabat, Op. Cit. hlm. 110 
setiap orang di antara kita harus mencari kesenangan sesama kita demi kebaikanya untuk membangunnya", (Roma 15:1-2).

B. S. Sijabat mengatakan bahwa; Tidak ada satu metode mengajar yang baik untuk setiap kesempatan dan jenis kegiatan belajar. Jadi, kalau ada peserta didik yang kurang bergairah dalam mengikuti pelajaran, guru harus sadar bahwa barangkali metode atau pendekatan yang dipilihnya kurang relevan dan ia harus berusaha mencari metode alternatif. ${ }^{21}$ Manusia membutuhkan motivasi atau rangsangan dari orang lain, untuk membangun hidupnya. Dalam konteks peranan guru PAK sebagai pembina iman peserta didik, maka para peserta didik membutuhkan motivasi dari guru PAK agar iman bertumbuh di dalam Tuhan Yesus Kristus dan menjadi berkat bagi sesamanya.

S. Nasution mengatakan bahwa; Mendorong manusia untuk membuat, jadi sebagai penggerak atau motor yang melepaskan energy.22 Tujuan guru Pendididikan Agama Kristen ialah memberi motivasi bagi para peserta didik agar belajar memiliki karakter Tuhan Yesus Kristus di dalam hidupnya. Para peserta didik binaan belajar mempraktekan firman Tuhan dalam hidupnya, prilaku hidupnya disesuaikan dengan firman Tuhan yang bertolak dari Alkitab dan setiap saat berupaya untuk tidak berbuat dosa di dalam hidupnya.

\section{Landasan Teologis Peranan Guru Pendidikan Agama Kristen}

\subsubsection{Menurut Perjanjian Lama.}

Di dalam perjanjian lama Tuhan memanggil Musa menjadi pemimpin bagi bangsa Israel. Bangsa Israel telah lama menjadi budak di Mesir, dan Allah mempersiapkan Musa untuk memimpin sekaligus membina hidup dan kerohanian bangsa Israel agar menjadi bangsa yang merdeka dari perbudakan di Mesir. Tuhan memanggil dan melatih Musa untuk memimpin bangsa Israel keluar dari Mesir dan supaya dapat menyembah dan memuji Tuhan tanpa penindasan bangsa Mesir dengan bebas. Allah memilihan dan memanggil Musa dinyatakan melalui beberapa pengalaman: diselamatkan dari ancaman mati. Musa menerima pernyataan dan panggilan dari Tuhan secara langsung yang disertai beberapa mujizat (semak duri yang menyalanyala, tongkat menjadi ular dan sebagainya). ${ }^{23}$ Sebagai orang pilihan Allah untuk memimpin dan membina kerohanian bangsa Israel, Musa menerima kuasa dari Allah. Tanpa kuasa Allah Musa tidak dapat membawa bangsa Israel yang adalah bangsa pilihan Allah, keluar dari perbudakan di Mesir. Perintah Allah kepada Musa disertai denga kuasa untuk membebaskan

21 B. S. Sidjabat, Op. Cit. hlm. 111

22 S. Nasution, Didaktik asas-asas mengajar, (Jakarta: Bumi Aksara, 2000), hlm. 76 hlm. 52-53

23 Denis Green, Pengenalan Perjanjian Lama, (Malang Jatim: Gandum Mas, 1984), 
bangsa Israel dari kekuasaan Firaun raja Mesir. Kuasa yang diberikan Allah kepada Musa untuk membawa bangsa Israel keluar dari Mesir menuju tanah Kanaan, merupakan anugerah Allah.

Musa menerima dan menyatakan kuasa Allah melalui kesepuluh tulah di Mesir yaitu: (1). Air menjadi darah; (2). Katak memenuhi seluruh tanah Mesir; (3). Nyamuk penghisap darah; (4). Lalat pikat penghisap darah; (5). Penyakit sampar; (6). Penyakit barah pada tubuh; (7). Hujan es; (8). Belalang pemakan tanaman di ladang; (9). Gelap gulita selama tiga hari; dan (10). Kematian anak sulung. Jadi kesepuluh tulah di Mesir dan penyebrangan laut Teberau di tanah kering merupakan manifestasi kuasa Allah yang diberikan kepada Musa. Dengan demikian, maka pemimpin dan pembina kerohanian seperti Musa termasuk guru PAK dalam membina pertumbuhan iman peserta didik, harus hidup dalam kekudusan untuk memperoleh kuasa Allah.

\subsubsection{Menurut Perjanjian Baru}

Yesus Kristus adalah pembina kerohanian di dalam Perjanjian Baru. Di dalam pelayanan-Nya dan pengajaran-Nya selain mengagumkan karena firman Tuhan yang diajarkan kepada murid-murid-Nya menarik perhatian dan minat banyak orang juga penuh kuasa. Dengan demikian, maka pelayanan Yesus Kristus patutlah diteladani oleh para pelayan gereja Tuhan termasuk guru PAK dalam membina pertumbuhan iman peserta didik, karena kehidupan Yesus Kristus yang menecerminkan ajaran-Nya.

Keteladanan hidup Yesus diwariskan kepada kedua belas murid-Nya dan memberi kuasa untuk mengusir roh-roh jahat dan untuk melenyapkan segala penyakit dan segala kelemahan. Kedua belas murid diutus Yesus untuk mempraktekan pengajaran dan keteladanan hidup yang telah diperagakanNya. Jadi Yesus Kristus sebagai pembina kerohanian yang penuh kuasa, memuridkan, mewariskan pengajaran dan kuasa-Nya kepada para muridNya. Guru PAK dalam membina pertumbuhan iman peserta didik, juga sebagai murid Yesus Kristus, yang harus menerima kuasa di dalam mengajarkan firman Tuhan dan mendidikan para peserta didiknya agar memiliki hidup dan karakter Yesus Kristus.

\section{Karakteristik Peranan Guru Pendidikan Agama Kristen}

\subsubsection{Peran Guru PAK Sebagai Pembina Iman.}

Bila dipahami maka profesionalisme guru PAK sebagai pengajar, maka fokusnya terarahkan pada usaha mentransferkan ilmu pengetahuan kepada para peserta didik. Pada sisi lain, selain sebagai pengajar, guru PAK juga berfungsi sebagai pendidik, yang harus mampu menanamkan nilai-niali etik dan moral Kristiani kepada para peserta didik. Selanjutnya seorang guru PAK juga berfungsi sebagai pemimpin yang bertugas menuntun para peserta didik dalam setiap interaksi belajar mengajar, baik di dalam 
maupun di luar kelas. Tulus TU.U mengatakan bahwa: Dengan bertitik tolak pada pengertian dan peranan seperti ini, maka yang diperlukan dari seorang guru PAK adalah kesadaran diri sebagai orang yang dipanggil Allah untuk melaksanakan tugas pelayanan kepada sesama manusia. ${ }^{24}$ Seorang guru PAK dalam melaksanakan profesionalismenya harus atas kesadaran diri sebagai orang yang dipanggil Allah untuk melayani sesama, yang fokusnya sebagai pembina kerohanian peserta didik.

Dalam praktik pembelajaran PAK di Sekolah Menengah Umum secara obyektif guru PAK, dan fungsi sebagai informator yang menjadikan dirinya sebagai sumber informasi bagi para peserta didik, juga sebagai motivator yang memotivasi untuk berhasil dalam tugas-tugas belajar. Jika fungsi sebagai informator dan motifator sudah berjalan dengan baik, maka fungsi sebagai evaluator untuk mengevaluasi perkembangan belajar para peserta didik. Jika ada problematika-problematika yang dihadapi para peserta didik, guru PAK bertindak sebagai konselor untuk membimbing dan menemukan solusi bagi pertumbuhan kerohanian para binaan. Guru PAK juga berfungsi sebagai organisator, komunikator, fasilator, mediator, dan sebagai konselor. Tentang peranan dan fungsi guru PAK, dalam kaitannya dengan tugas panggilannya sebagai pendidik maka seorang guru PAK berperan sebagai pembina kerohanian. Dengan demikian maka Noordegraf menyatakan bahwa; Substansi dari keberadaan guru PAK sebagai seorang pembina adalah bagaimana guru PAK itu dapat membentuk kehidupan rohani dari anak didik. Dalam kaitan ini semua pola dan cara pembinaan yang dilakukan haruslah mencirikan pola Yesus Kristus. Karena itu persyaratan yang mutlak dipahami adalah, seorang guru PAK harus mengenal peserta didik dengan sebaik-baiknya. Untuk itu guru seyogianya selalu hidup dalam ajaran yang benar. ${ }^{25}$ Keseluruhan arti fungsi dan peran guru PAK akan dapat dilaksanakan dengan baik dan menghasilkan, apabila guru PAK memiliki kerendahan hati, dedikasi yang tinggi, rela berkorban yang meneladani kehidupan dan karakter serta mengandalkan Tuhan Yesus Kristus.

\section{Kualifikasi Guru PAK Sebagai Pembina Kerohanian}

\subsubsection{Guru PAK Sudah Lahir Baru}

Seorang guru PAK sangat berperanan dalam Pendidikan Agama Kristen, sebagai pendidik kristen sangat berpengaruh dalam panggilan dan profesinya. Karena itu maka kualifikasi terutama bagi seorang guru PAK adalah sudah harus lahir baru atau bertobat. Kerohanian seseorang guru PAK harus mempunyai pengalaman pertobatan dengan pengenalan Tuhan Yesus

24 Tulus. TU.U, Dasar konseling Pastoral, (Yogyakarta: Andi Ofset, 1987), hlm. 12

25 Noordegraf, Orientasi diakonal Gereja, (Jakarta: BPK, t.th), hlm. 31 
bersumber hidupnya dari Alkitab. Mary Go Setiawani menyatakan bahwa; Seseorang yang tidak memiliki hidup Kristus, tentu tak sanggup membina hidup, apalagi mempengaruhi hidup orang lain. Oleh kelahiran baru bagi seorang guru adalah syarat utama bagi seorang guru Kristen. ${ }^{26}$ Kelahiran baru seorang guru PAK merupakan syarat terpenting untuk membina kerohanian para peserta didik, sebab tanpa proses kelahiran baru mustahil bagi seorang guru PAK untuk dapat mencerminkan kehidupan dan karakter Tuhan Yesus Kristus dalam panggilannya. Melalui kelahiran baru orang percaya menerima watak dan karakter Tuhan Yesus, yang akan terlihat dari kehidupannya sehari-hari.

Bruce Milne, menyatakan: Yang telah mengalami kelahiran baru selalu mengutamakan hal-hal yang dari Allah, dalam tugasnya sebagai guru akan menolak dosa, dan manaati serta melayani Tuhan segenap hati. ${ }^{27}$ Jadi seorang guru PAK yang sudah lahir baru, akan menjadi teladan hidup para peserta didik dalam pengenalan akan Tuhan. Bahkan tujuan hidupnyapun diperbaharui, seperti tujuan hidup Tuhan Yesus yaitu menjadi semua orang menjadi murid-Nya.

\subsubsection{Guru PAK Memiliki Karakter Tuhan Yesus.}

Kesaksian hidup seorang guru PAK yang baik dan benar, dapat mempengaruhi sikap dan cara hidup setiap peserta didik. Karena tidak ada seorang guru PAK yang menyampaikan kebenaran dengan berhasil, kalau hidupnya tidak meneladani kehidupan dan karakter Tuhan Yesus.

Dalam menyampaikan Injil kepada para peserta didik, seorang guru PAK dituntut menajdi teladan, karena guru tidak hanya berterori dalam menyampaikan materi saja, tetapi lebih dari pada itu sikap hidupnya lebih utama untuk diteladani para peserta didiknya. E. G. Homrighausen dan I. H. Enklaar tentang syarat guru Kristen mengatakan: Seorang guru harus mempunyai pribadi yang dan tinggi. ${ }^{28}$ Kesaksian hidup yang baik sangat berhubungan dengan pengalaman rohani yang dialami oleh seorang guru PAK. Karena itu sebagai guru PAK hendaknya mempunyai kepribadian yang berkarakter Tuhan Yesus, yang dapat diteladani para peserta didik.

Stephen Tong menyatakan, bahwa: Kalau seorang pendidik memiliki kepribadian yang belum beres atau tidak sesuai dengan kedudukan atau kewajiban sebagai pendidik, maka pribadinya akan merusak orang lain sekalipun dia memiliki teori pendidikan yang sangat baik yang terus menerus keluar dari mulutnya. ${ }^{29}$ Selanjutnya Mary Go Setiawani mengatakan bahwa;

\footnotetext{
${ }^{26}$ Mary Go Setiawni, Pembaruan Mengajar, (Jakarta: BPK Gunung Mulia, 2005), hlm. 11

27 Ibid, hlm 11

28 Bruce Millne, Mengenali Kebenaran, (Jakarta: Gunung Mulia, 2002), hlm. 258

${ }^{29}$ Stephen Tong, Seni Membentuk Karakter, (Jakarta: Momentum, 2005), hlm. 165
} 
Bila guru sendiri tidak suka beribadah, tidak merasa tertarik dalam membaca Alkitab dan berdoa, juga tidak memiliki kesaksian hidup yang baik, maka bagaimana mungkin dapat memberikan pengaruh yang baik kepada peserta didiknya. ${ }^{30}$ Dapat dipastikan bahwa keberhasilan seorang guru PAK karena memiliki karakter Tuhan Yesus bukan hanya kompetensinya sebagai guru PAK, dan kepribadian itulah yang akan mempengaruhi para peserta didik.

\subsubsection{Guru PAK Berpengetahuan Dasar Sebagai Guru}

Guru yang profesional mempunyai kualitas sebagai pengajar yang diakui dan dihargai oleh masyarakat, serta menguasai betul materi yang diajarkan. Hal ini dituntut terhadap profesional guru dan ini tidak lepas dari pengetahuan yang dimilikinya. B.S. Sidjabat menyatakan: Untuk membentuk profesi, lembaga pendidikan harus terus berupaya memperkaya kualitas pendidikan prajabatan guru. Pendidikan yang tepat harus terus diusahakan agar calon guru memiliki penguasaan bahan yang dapat diandalkan; memiliki penguasaan teori dan keterampilan guru, serta memiliki kemampuan memperagakan untuk kerja sebagai calon guru. ${ }^{31}$ Dari perspektif profesionalisme maka seorang guru PAK, harus memprioritaskan kualitas pelayanan yang unggul tentang pengajaran iman Kristen kepada peserta didik agar memiliki pengetahuan yang benar-benar bersumber dari Alkitab. Jadi untuk mencapai profesional guru yang berkualitas tersebut, bahwa hendaknya mengisi dirinya dengan pengetahuan Alkitab.

Stephen Tong mengatakan: Seorang guru harus mempunyai pengetahuan kebenaran dan segala sesuatu yang diperlukan untuk menjadi bahan penyelidikan yang cukup dan tepat. ${ }^{32}$ Dalam pengertian bahwa guru PAK yang berhasil hendaknya selalu belajar untuk memperlengkapi diri dengan pengetahuan Alkitab, menguasai metode mengajar, menguasai perkembangan peserta didik untuk bisa membimbing kerohaniannya. Janse Belandia. Non - Serrona, menyatakan: Guru dan menyesuaikan materi sesuai dengan kebutuhan peserta didik, menggunakan beragam metodologi secara kreatif sesuai dengan materi dan situasi kela, luwes dalam melakasnakan rencana dan selalu mencari pengajar yang efektif. ${ }^{33}$ Jadi guru yang profesioanal adalah guru yang mengenal tentang dirinya, yaitu pribadi yang terpanggil untuk mendampingi peserta didik untuk belajar, dan selalu berupaya untuk terus-menerus meningkatkan prestasi para peserta didik yang dibinanya. Kegagalan maupun keberhasilan para peserta didik dalam

30 Ibid, hlm. 8-9

31 Ibid, hlm. 33

32 Ibid, hlm. 22

33 Belandia. Non - Serona, Profesionalisme Guru dan Bingkai Materi, (Bandung: Bina Media Informasi, 2004), hlm. 25 
belajar, merupakan tanggung jawab guru sebagai sumber transfer ilmu pengetahuan dan keteladanan karakter.

\subsubsection{Peranan Roh Kudus Dalam Pribadi Guru PAK.}

Seorang guru PAK sangat bergantung pada kuasa Roh Kudus, yang dapat memampukannya untuk mengajarkan Firman Tuhan para pserta didiknya. B. S. Sidjabat menyatakan bahwa: Seorang guru Kristen perlu menyadari bahwa peranan Roh Kudus bukan hanya berlangsung dalam rangka pendewasaan iman, dan peningkatan kualitas atau kesadaran akan kesucian hidup, tetapi juga didalam rangka mengembangkan profesi sehari-hari. Roh Kudus ingin menyatakan kuasa dan kehadiran-Nya di dalam diri dan melalui seseorang. Karena itulah guru bidang studi apapun, tetap memerlukan kehadiran Roh Kudus. ${ }^{34}$ Dalam mengembangkan profesi sebagai guru PAK peranan kuasa Roh Kudus sangat penting, karena tanpa kuasa Roh Kudus kehidupan seorang guru PAK tidak akan berdampak bagi para nara didiknya. Dalam hal ini faktor persekutuan pribadi dengan Tuhan Yesus, merupakan faktor terpenting dalam kehidupan yang penuh dengan Roh Kudus. Tentang pengembangan profesi sebagai guru PAK dan peranan Roh Kudus dalam kehidupannya.

E.G. Homrighausen dan I. H. Enklaar mengatakan bahwa: Iman, kasih dan harapan itu merupakan dasar kekristenan kita. Tetapi disamping itu perlu pula kita membuka jiwa dan hidup kita seanteronya bagi api yang suci, yang hendak dinyatakan Tuhan dalam diri kita dengan Roh-Nya yang kudus. ${ }^{35}$ Pribadi yang penuh dengan Roh Kudus termotivasi dan bergerak secara dinamis memberi kemampuan menaati dan melayani Tuhan menurut kehendak-Nya. Hal yang sama juga dijelaskan oleh W.A. Henrichen yang mengatakan bahwa; Karena itu kita harus bersandar kepada Tuhan dan memohon supaya Roh Kudus senantiasa membimbing kita dan bekerja di dalam hati setiap anak agar kebenaran Tuhan dinyatakan kepada mereka pribadi. ${ }^{36}$ Kedua pendapat ini menekankan bahwa kebergantungan kepada Roh Kudus memegang peranan penting dalam menyampaikan kebenaran kepada orang lain, dalam hal guru Pak mengajar atau mendidik para peserta didiknya. Kemampuan dan kecakapan seorang guru PAK untuk mentransferkan ilmu pengetahuannya dan keteladanan karakter Tuhan Yesus dari pribadinya kepada peserta didik karena peranan Roh Kudus, yang dapat merubah sikap peserta didik. Karena itu seorang guru PAK harus hidup dalam persekutuan yang harmonis dengan Tuhan.

${ }^{34}$ Ibid, hlm. 75

35 Ibid, hlm. 12

36 W.A. Henrichsen, Cara Melatih Murid Kristus, (Bandung: Yayasan Kalam Hidup, 1994), hlm. 90 


\section{Hakekat Pertumbuhan Iman Peserta Didik}

\subsection{Pengertian Pertumbuhan Iman Peserta Didik}

Brian J. Bailey mengatakan bahwa: Iman adalah sesuatu yang tidak bisa di lihat dan dipegang. Iman bukanlah suatu perasaan atau intelek manusia. ${ }^{37}$ Menurut Kamus Besar Bahasa Indonesia menjelaskan bahwa iman adalah "Kepercayaan" (yang berkenaan dengan Agama). Keyakinan dan kepercayaan kepada Allah, nabi, kitab dan sebagainya tidak akan bertentangan dengan ilmu. ${ }^{38}$ Derek Prince mengatakan: Iman merupakan suatu "Dasar" suatu keyakinan, sesuatu yang sungguh nyata dan pasti yang sudah ada di dalam kalbu manusia yang sudah manusia miliki sekarang juga. ${ }^{39}$ Iman tidak didasarkan pada bukti-bukti, tetapi didasarkan atas kebenaran-kebenaran dan fakta-fakta yang kekal dan tidak kelihatan yang dikemukakan Firman Tuhan. Iman begitu nyata dari segala sesuatu yang tidak bisa dilihat manusia, karena melalui iman juga manusia boleh berjalan dengan penuh kepercayaan dan keyakinannya kepada Tuhan (Ibrani 11:1).

Dengan mempelajari sesungguhnya bahwa iman timbul dari pendengaran Firman Tuhan (Roma 10:17), maka iman itu berkaitan langsung dengan Firman Tuhan. Guru PAK bertanggungjawab bagi pertumbuhan iman para peserta didik, melalui pengajaran firman Tuhan dan keteladanan hidupnya sebagai praktek imannya.

Jadi yang disebut dangan iman menurut Alkitab adalah percaya Allah berkata benar di dalam FirmanNya (bahwa Ia sungguh-sungguh apabila Ia menyatakan sesuatu di dalam Firman-Nya).40 Melalui iman yang timbul karena pengajaran firman Tuhan oleh guru PAK, akan membawa para peserta didik menuju kesempurnaan. Kesempurnaan iman orang percaya di dunia ini, harus dinyatakan melalui perbuatan agar dilihat orang lain dan percaya kepada Allah di dalam Tuhan Yesus Kristus. Iman para peserta didik merupakan suatu tanda yang menggambarkan hubungan manusia dengan Allah, karena oleh iman para peserta didik bisa mengatasi berbagai masalah hidup dengan pemikiran yang benar. Karena Alkitab memperingatkan bahwa iman manusia akan mengalami ujian yang cukup berat, ujian iman itu diperlukan untuk membuktikan kemurniannya dan untuk pembentukkan suatu karakter Kristen yang kuat di dalam diri manusia.

Pemikiran yang benar akan menghasilkan kepercayaan yang benar. Pemikiran yang benar timbul dari pengetahuan akan Firman Allah. ${ }^{41}$ Untuk itu para peserta didik harus membaca dan memahami serta mempraktek

\footnotetext{
${ }^{37}$ Brian J. Bailey, Pilar-Pilar Iman, (Jakarta: Voice Of Hope, 2005), hlm.1

38 Tim Penyusun, KBBI, Op. Cit., hlm. 427

39 Derek Prince, Foundations For Righteous Living, (Jakarta: Derek Prince Ministries Indonesia, 2005), hlm. 144

40 Ibid. hlm. 56

41 Billy Joe Daugherty, Kuasa Iman, ( Jakarta: Yayasan Kalam Hidup, 2004), hlm. 15
} 
perkataan-perkataan iman, sehingga iman bertumbuh berdasarkan Firman Tuhan.

\subsection{Landasan Teologi Pengertian Iman}

\subsubsection{Pengertian Iman Menurut Perjanjian Lama}

Dalam perjanjian lama kata iman ada tiga hal adalah: he'e min, Batach, dan chasah. ${ }^{42}$ Jadi maksud dari kata he'e min adalah bentuk hiphil dari aman. ${ }^{43}$ Menurut leksikon bahasa Ibrani Brown-Driver-Briggs, arti dasar kata ini dalam bentuk Qal adalah "meneguhkan atau mendukung."44 Dengan demikian, bentuk hiphil berarti "menyebabkan untuk mendukung" atau "menyebabkan menjadi teguh," jika diterapkan dengan seseorang maka kata ini berarti "menyebabkan seseorang untuk mendukungmu dengan demikian didapatkan arti "mempercayai atau mempercayakan diri kepada seseorang." 45 Seperti yang ada dalam kitab Kejadian 15:6 menyatakan "percayalah Abram kepada Tuhan maka Tuhan memperhitungkan hal itu kepadanya sebagai kebenaran." Kepercayaan Abram kepada Tuhan, bukti bahwa Abram sungguh-sungguh percaya atau mempercayakan hidupnya kepada Allah dengan imannya yang sungguh-sungguh.

Kata iman yang lainnya adalah batach, yang berarti "yakin akan, bersandar pada, mempercayai."46 Contohnya dalam Mazmur 25:2 menyatakan Allahku, kepada-Mu aku percaya: Janganlah kiranya aku mendapat malu; janganlah musuh-musuhku beria-ria atas aku. Jadi, dalam Perjanjian Lama untuk iman adalah chasah, yang berarti "mencari perlindungan." 47 Contohnya dalam Mazmur 57:2 menyatakan "Kasihilah aku, ya Allah, kasihilah aku, sebab kepada-Mulah jiwaku berlindung; dalam naungan sayap-Mulah jiwaku berlindung: dalam naungan sayap-Mu aku akan berlindung, sampai berlalu penghancuran itu." Dari ayat Firman Tuhan di atas jelaslah bahwa tempat perlindungan pemazmur hanyalah kepada Tuhan penciptanya.

Iman adalah inti dari kehidupan umat Allah, jelas bahwa masyarakat Perjanjian Lama menganggap Tuhan satu-satunya yang layak menjadi andalan. ${ }^{48}$ Kemudian umat Tuhan tidak mengandalkan sesuatu apapun yang dilakukannya atau yang dilakukan orang lain. Tetapi yang manusia andalkan atau harapkan adalah hanya Tuhan. Seperti dalam Mazmur 18:2-3

42 Antony A. Hoekema, Diselamatkan Oleh Anugerah, (Surabaya: Momentum, 2006),

43 Ibid. hlm. 176

44 Ibid. hlm. 176

45 Ibid. hlm. 176

46 Ibid. hlm. 176

47 Ibid. hlm. 177

48 Tim Penyusun, Ensiklopedi Alkitab Masa Kini Jilid I, (Jakarta: Yayasan Komunikasi Bina Kasih, 1992), hlm.431 
menyatakan: Ia berkata: "Aku mengasihi Engkau, ya TUHAN, kekuatanku! Ya TUHAN, bukit batuku, kubu pertahananku dan penyelamatku: Allahku, gunung batuku, tempat aku berlindung, perisaiku, tanduk keselamatanku, kota bentengku." Pemazmur menyatakan dengan jelas bahwa iman dapat di pautkan dengan pasti pada Allah sebagai bukti batu, kubu pertahanan dan penyelamat,. Karena yang dipercayai pemazmur ialah Allah, ketulusan hatinya adalah bukti kepercayaannya kepada Allah. Di dalam kitab Mazmur iman di gambarkan dengan berbagai cara: sebagai kepercayaan kepada Allah, mendapatkan perlindungan di dalam-Nya, memberikan diri manusia kepadaNya dan sebagainya. ${ }^{49}$ Hal ini jelas bahwa pemazmur berusaha supaya hidupnya benar, dan jelas juga pada dasarnya pemazmur mengajar orang supaya berharap kepada Allah, dan ini hanya cara lain mengajak orang hidup dari iman.

\subsubsection{Pengertian Iman Menurut Perjanjian Baru}

Iman yang dimaksud dalam Perjanjian Baru itu sesunguhnya terdiri dari beberapa aspek atau segi. Pada dasarnya iman selalu selaras dengan defenisi yang diberikan di dalam surat Ibrani 11:1 yaitu "Iman adalah dasar dari segala sesuatu yang kita harapkan dan bukti dari segala sesuatu yang tidak kita lihat." Meskipun demikian sifat benar tersebut diungkapkan melalui berbagai bentuk yang berlainan namun saling berkaitan.

Iman sebagai suatu hubungan pribadi yang terjalin antara Allah dan setiap insan yang percaya kepada-Nya, yang tidak pernah terputus dan mempengaruhi segala segi kehidupannya. ${ }^{50}$ Iman yang memotivasi, mengarahkan dan memampukan para peserta didik untuk bisa melakukan segala sesuatu. Hanya oleh iman maka para peserta didik dapat hidup dengan benar dihadapan Tuhan dan sesamanya.

Ronald Dunn membahas istilah iman dalam bahasa Yunani "elenschos" yaitu iman diterjemahkan sebagai "keyakinan" dan "percaya," berarti bersandarnya seluruh kepribadian manusia kepada Allah atau Mesias, dengan kepercayaan dan keyakinan penuh akan kuasa hikmat dan kebaikannya. ${ }^{51}$ Dalam istilah ini juga tercakup gagasan tentang keyakinan intelektual. Maka didefenisikan iman sebagai suatu kegiatan akal dan kehendak Allah terhadap manusia. Karena keyakinan para peserta didik atas kebenaran akan Allah, bahwa Allah adalah pencipta dan penguasa segala sesuatu, dan pemberi keselamatan melalui Kristus. Dalam Perjanjian Baru pengertian iman melibatkan penerimaan atas suatu rangkaian kebenaran yang didasarkan pada kesaksian para rasul atau orang-orang lainnya

${ }^{49}$ Anthony A. Hoekema, Op. Cit., hlm. 179

${ }^{50}$ Derek Prince, Iman Yang Olehnya Kita Hidup, (Jakarta: Derek Prince Ministries Indonesia, 2005), hlm. 27

${ }^{51}$ Ronald Dunn, Krisis Iman, (Malang: Gandung Mas, 1997), hlm. 26 
termasuk para peserta didik yang menyebarkan kesaksian itu, dan suatu kepercayaan pribadi kepada Kristus sebagai juruselamat.

Iman digambarkan dalam Perjanjian Baru dengan berbagai ungkapan yang menarik. Iman disebut tindakan untuk datang kepada Kristus. ${ }^{52}$ Seperti dalam Yohanes 6:37 menyatakan "Semua yang diberikan Bapa kepada-Ku akan datang kepada-Ku dan barangsiapa datang kepada-Ku, ia tidak akan kubuang." Iman dilihat sebagai tindakan meninggalkan diri manusia sendiri termasuk para peserta didik untuk datang kepada Kristus, tidak lagi menempatkan kepercayaan kepada diri sendiri tetapi hanya percaya kepada Yesus Kristus. Para peserta didik dapat menemukan di dalam Kristus pengharapan keselamatan, sukacita dan juga tujuan hidupnya.

Dalam Perjanjian Baru, iman ialah sikap yang di dalamnya seseorang melepaskan andalan pada segala usahanya sendiri untuk mendapat keselamatan. ${ }^{53}$ Iman jelas merupakan salah satu konsepsi penting dalam seluruh Perjanjian Baru. Iman berarti memegang teguh janji Allah di dalam Kristus dengan memautkan seluruh kepercayaan para peserta didik kepada karya Kristus yang seutuhnya demi keselamatan, dan kepada kekuasaan Roh Kudus demi kekuatan sehari-hari.

Pada perjanjian baru asal usul iman diungkapkan oleh Paulus dalam Roma 10:17 bahwa "Iman timbul dari pendengaran dan pendengaran oleh firman Kristus." Iman tidak lahir dari dalam diri seseorang berbeda dengan iman alami yaitu sifat dari dalam diri manusia, sedangkan iman Alkitabiah ditanamkan oleh Allah. ${ }^{54}$ Iman para peserta didik timbul karena mendengarkan firman Tuhan, maksudnya adalah iman yang alkitabiah, iman itu harus datang dari suatu sumber diluar dirinya. Iman tidak ditimbulkan oleh diri manusia, melainkan adalah pemberian Allah. Iman berasal dari Dia: Allah yang memulai iman dan menanamkannya dalam diri manusia. ${ }^{55}$ Seperti dalam surat 2 Petrus 1:1 menyatakan "dari simon Petrus, hamba dan rasul Yesus Kristus, kepada mereka yang bersama-sama dengan kami memperoleh iman oleh karena keadilan Allah dan juruslamat kita, Yesus Kristus." Demikian juga dalam Efesus 2:8 menyatakan: "Sebab karena kasih karunia kamu diselamatkan oleh iman itu bukan hasil usahamu, tetapi pemberian Allah." Jadi kesimpulannya adalah awal hingga akhir keselamatan para peserta didik adalah karya Allah. Maka dalam segala sesuatu yang berhubungan dengan keselamatan para peserta didik berasal dari Allah, termasuk juga iman untuk menerima kasih karunia-Nya.

Iman Kristen menyatakan keselamatan para peserta didik adalah anugerah Allah, tidak ada fungsi para peserta didik untuk menyelamatkan

\footnotetext{
52 Anthony A. Hoekema, Op. Cit., hlm. 182

53 Tim Penyusun, YKBK, Op. Cit., hlm. 431

54 Ronald Dunn, Op. Cit., hlm. 49

55 Ibid. hlm 50-51
} 
dan membebaskan dirinya dari belenggung dosa kalau tidak melalui Pengorbanan Yesus Kristus di kayu salib. Jadi iman kepada Kristus itulah yang menyelamatkan para peserta didik. Peter David dalam Henk ten Napel, menyatakan: "Iman tanpa perbuatan tidak mungkin berada: jika tidak ada perbuatan, maka tidak ada iman. ${ }^{56}$ Pernyataan ini mengkonfirmasikan Yakobus 2:26, bahwa Iman harus dinyatakan dalam perbuatan sebagai bukti bahwa Allah hidup di dalam orang percaya termasuk para peserta didik. Untuk itu perbuatan adalah bukti dari iman para peserta didik kepada Yesus Kristus.

\section{Kesimpulan}

Bentuk-bentuk pembinaan iman peserta didik merupakan program dan tanggung jawab guru Pendididikan Agama Kristen. W. S. Winkel dan M. M. Sri Hastuti mengatakan bahwa; Bentuk bimbingan menunjuk pada jumlah orang yang diberikan pelayanan bimbingan. ${ }^{57}$ Dalam menentukan bentukbentuk pembinaan pertumbuhan iman peserta didik, guru Pendididikan Agama Kristen mempersiapkan waktu, metode dan proses pembinaan sesuai dengan jumlah peserta didik binaan. Hal ini perlu, karena tujuan diadakannya pembinaan pertumbuhan iman peserta didik agar guru Pendididikan Agama Kristen dapat mengetahui proses pertumbuhan iman dan perubahan karakter setiap peserta didik yang sedang dibinaannya.

Singgih D. Gunarsa dan Y. Singgih D. Gunarsa, mengatakan bahwa; Tentunya macam bimbingan harus diberikan sedemikian rupa, sehingga tujuan tersebut pasti akan tercapai. ${ }^{58}$ Bentuk-bentuk bimbingan terhadap pertumbuhan iman peserta didik, dilakukan dengan tujuan agar iman peserta didik bertumbuh dan menjadi dewasa di dalam Tuhan Yesus Kristus, dan dapat diaplikasikan melalui karakter hidupnya. Karena itu dalam proses pembinaan dan pembimbingan bagi pertumbuhan iman peserta didik, butuh metode yang tepat untuk mencapai sasaran guru Pendididikan Agama Kristen dalam pembimbingan untuk dicapai yaitu kedewasaan iman.

DLeroy Eims menyatakan bahwa; Sebenarnya keinginan Allah untuk membimbing kita jauh lebih besar dari pada keinginan umat-Nya untuk di bimbing.59 Program pembinaan dan pembimbingan iman orang percaya termasuk para peserta didik, merupakan program dan intruksi Allah bagi orang-orang percaya atau umat pilihan-Nya (Efesus 4:11-12). Guru

${ }^{56}$ Henk ten Napel, Jalan yang Lebih Utama Lagi, (Jakarta: BPK Gunung Mulia, 2001), hlm. 195

57 W. S. Winkel dan M. M. Sri Hastuti, Bimbingan dan konseling, (Yogyakarta: Media abadi, 2004), hlm. 111

58 Singgih D. Gunarsa dan Y. Singgih D. Gunarsa, Psikologi untuk membimbing, (Jakarta: BPK Gunung Mulia, 2007), hlm. 34

${ }^{59}$ Leroy Eims, doa bukan sedar kata-kata, (Jakarta: Gandum Mas, 1982), hlm. 8 
Pendididikan Agama Kristen adalah orang yang dipanggil Tuhan untuk mengerjakan program Allah yaitu memperlengkapi orang-orang kudus bagi pelayanan pekerjaan Tuhan. Bentuk pembinaan dan pembimbingan bagi pertumbuhan iman peserta didik, haruslah berdasarkan Alkitab sebagai buku pedoman guru Pendididikan Agama Kristen. Karena untuk mengadakan berbagai jenis pembinaan dan pembimbingan kepada para peserta didik harus berorientasi pada program kerja Allah yaitu memperlengkapi orangorang kudus bagi pekerjaan pelayanan bagi pembangunan Tuhan Kristus atau gereja Tuhan.

Bentuk-bentuk pembinaan dan pembimbingan bagi pertumbuhan iman peserta didik banyak, namun penulis hanya beberapa diantaranya ialah:

\subsubsection{Melalui Persekutuan.}

Persekutuan doa di sekolah merupakan wadah yang dipakai guru Pendididikan Agama Kristen untuk membina pertumbuhan iman para peserta didik. Pembinaan pertumbuhan iman para peserta didik dapat dibangun melalui persekutuan doa, supaya para peserta didik dibiasakan hidup dalam komunitas iman Kristen (Ibrani 10:24-25). Bruce Milne menyatakan bahwa: Istilah persekutuan berasal dalam bahasa Yunani yaitu "Koinonia" kata koinonia pada dasarnya berarti bersama-sama menerima bagian dalam sesuatu. ${ }^{60}$ Persekutuan doa khusus bagi para peserta didik, sesuai bahasa aslinya yaitu "Koinonia" yang penekananya pada kebersamaan untuk saling memperhatikan, saling memotivasi, saling menasehati dan sama-sama mempersiapkan diri menyambut kedatangan Tuhan kedua kalinya. Jadi para peserta didik melalui pembinaan iman oleh guru Pendididikan Agama Kristen di persekutuan doa, dilatih untuk hidup dalam kebersamaan komunitas Kristiani sehingga membiasakan diri untuk saling memperhatikan, memotivasi, menasehati dan bersama-sama menantikan kedatangan Tuhan Yesus kedua kalinya.

Ruth. F. Selan menyatakan bahwa; Kemudian persekutuan orangorang Kristen yang di gambarkan sesuai koinonia yang berarti persekutuan di mana setiap anggota persekutuan saling menolong, saling menguatkan, saling menasehati, dan saling melayani. ${ }^{61}$ Tujuannya agar para peserta didik dibina pertumbuhan imannya melalui persekutuan doa dengan orang-orang seiman untuk dilatih dan dipersiapkan untuk saling menolong, saling menguatkan, saling menasehati, dan saling melayani, dan Allah yang menginginkan umat-Nya hidup dalam persekutuan, akan memperhitungkan persekutuan umat-Nya itu sebagai upah (I Korintus 15:58).

60 Bruce Milne, mengenalin kebenaran, (Jakarta: BPK Gunung Mulia, 2003), hlm. 308

61 Ruth. F. Selan, Pedoman pembinaan warga jemaat, (Bandung: Yayasan Kalam Hidup, 2006), hlm. 20 
Mangara Sinamo menyatakan bahwa; Jadi, setiap orang yang percaya kepada Yesus Kristus selalu menjalani yang namanya persekutuan, karena persekutuan adalah jati diri orang percaya. ${ }^{62}$ Persekutuan doa adalah identitas orang-orang pilihan Allah, maka sangat perlu bagi guru Pendididikan Agama Kristen untuk membentuk suatu persekutuan doa bagi para peserta didik di sekolah, sehingga membiasakan diri hidup dalam persekutuan sebagai anak-anak Allah. Di dalam persekutuan doa di sekolah, guru Pendididikan Agama Kristen mengajarkan, membina, menuntun dan merangkul untuk saling memperhatikan, saling menasehati, saling memotivasi sebagai bagian yang sangat esensial dari kehidupan umat Allah

Stephen Tong menyatakan bahwa; Allah itu terang adanya, maka manusia di mungkinkan bisa berjalan di dalam suatu persekutuan yang sehat.63 Persekutuan doa di sekolah merupakan wadah untuk Allah menyatakan terang-Nya yang ajaib, maka Allah menghendaki dan merindukan adanya persekutuan dengan umat-Nya. Sebab di dalam persekutuan umat Allah termasuk para peserta didik untuk belajar mempraktekan imannya supaya bertumbuhan dan menjadi dewasa di dalam Tuhan Yesus Kristus.

Paulus Lilik Kristianto menyatakan bahwa; Namun yang perlu di lakukan adalah doa (pertobatan kepada Allah secara terus menerus), belajar (merenungkan Firman Allah) dan menyembah (mengungkapkan keindahan, kebaikan dan kebesaran Allah melalui kata-kata, dan simbol baik secara sendiri maupun bersama-sama. ${ }^{64}$ Bukti kehidupan umat Allah dalam persekutuan doa adalah pertobatan, kesaksian dan penyembahan. Dalam hubungan dengan peranan guru Pendidikan Agama Kristen sebagai pembina iman peserta didik, maka guru Pendididikan Agama Kristen harus membimbing para peserta didik binaannya untuk mengalami pertobatan melalui perjumpaan pribadi dengan Tuhan Yesus Kristus.

\subsubsection{Berdoa bersama}

Billy Joe Daugherty menjelaskan bahwa; Doa berarti mengungkapkan apa yang kita dengar dan mempercayai. Doa harus berasal dari roh dan mengungkapkannya lewat tubuh jasmani. ${ }^{65}$ Berdoa adalah kegiatan yang esensial dalam perekutuan umat Allah termasuk para peserta didik. Karena itu para peserta didik perlu pembina untuk mengajarkan, melatih dan memotivasi untuk berdoa. Guru Pendididikan Agama Kristen sebagai

62 Mangara Sinamo, Kumpulan ilustrasi penggugah inspirasi, (Jakarta: Cv. Le Peridien, 2007), hlm. 123

63 Stephen Tong, Peta dan Teladan Allah, (Jakarta: Lembaga Reformed Injili Indonesia, 1994), hlm. 56

${ }^{64}$ Paulus Lilik Kristianto, Prinsip dan Pratik Pendidikan Agama Kristen, (Yogyakarta: ANDI, 2006), 80

65 Billy Joe Daugherty, Op. Cit., hlm. 23 
pembina iman peserta didik perlu untuk mengajarkan kepada para peserta didik tentang (1). Cara berdoa; (2). Materi doa; (3). Esensi doa, (4). Tujuan berdoa; (5). Sikap doa.

Rick Osborne menyatakan bahwa; Doa merupakan suatu hal yang utama dalam kehidupan remaja Kristen dan juga bagi kehidupan umat-Nya yang percaya kepada-Nya karena berdoa merupakan unsur komunikasi dalam hubungan kita dengan Tuhan, dan juga suatu hubungan dengan Allah harus menjadi landasan bagi segala sesuatu di dalam hidup remaja. ${ }^{66}$ Kehidupan dalam persekutuan dengan Allah melalui persekutuan orang percaya, doa merupakan salah satu faktor penting maka umat Allah termasuk para peserta didik membutuhkan pengetahuan yang benar tentang doa dan dibimbing untuk belajar memfokuskan diri pada kehidupan doa.

Charlie Riggs menyatakan bahwa: Doa adalah suatu sikap bergantung kepada Allah. ${ }^{67}$ Guru Pendididikan Agama Kristen dalam peran sebagai pembina iman peserta didik harus terus-menerus membina para peserta didik untuk memiliki gaya hidup yang berdoa, karena orang yang kehidupan doanya teratur menunjukkan bahwa orang tersebut membutuhkan atau menggantungkan hidupnya kepada Allah. Oleh karena itu peserta didik harus dibina, dituntun dan dibimbing untuk berikan seluruh hidupnya untuk berdoa, karena orang yang suka berdoa adalah sikap hati yang mensyukuri kehidupannya sebagai anugerah Allah, sebagai ekspresi imannya kepada Allah.

\subsubsection{Pemahaman Alkitab.}

Alkitab itu firman Tuhan yang adalah kekuatan Allah yang sanggup menyelamatkan setiap orang yang percaya. Di dalam Alkitab yang adalah firman Tuhan itu nyata kebenaran Allah yang bertolak dari iman dan memimpin kepada iman. Charlie Riggs menyatakan bahwa; Alkitab telah bertahan sepanjang zaman sebab Alkitab adalah Firman Allah. ${ }^{68}$ Kemampuan Alkitab mempertahankan eksistensinya dari berbagai serangan dari zaman ke zaman, sebagai pembuktian bahwa Alkitab benar-benar adalah Firman Allah yang kekal dan orang benar akan hidup oleh iman yang bertumbuh karena memahami Alkitab.

Pemahaman Alkitab itu penting karena di dalam Alkitab terkandung janji-janji Allah bagi setiap orang percaya yang pasti tergenapi bagi setiap orang percaya yang berpegang pada janji-janji Allah itu. Dengan demikian, maka peserta didik sebagai generasi penerus iman Kristen, harus diberikan

\footnotetext{
${ }^{66}$ Rick Osborne, Cara Mengajar Anak-anak Berdoa, (Batam: centre, Gospel Press, 2002), hlm. 60

${ }^{67}$ Charlie Riggs, Belajar berjalan dengan Allah, (Jakarta: Persekutuan Pembaca Alkitab, 2005), hlm. 101

68 Ibid. hlm. 83
} 
pemahaman firman Tuhan yang Alkitabiah, agar iman kepada Allah di dalam Tuhan Yesus Kristus terus bertumbuh. Guru Pendididikan Agama Kristen membimbing para peserta didik binaannya untuk mempelajari dan memahami Alkitab dalam setiap kegiatan persekutuan doa peserta didik. Melalui pemahaman Alkitab, guru Pendididikan Agama Kristen membimbing para peserta didik untuk menerapkan firman Tuhan di dalam kehidupannya sebagai bukti dari pertumbuhan imannya kepada Allah di dalam Tuhan Yesus Kristus.

R. J. Porter M.A menyatakan bahwa; Alkitab adalah salah satu yang menjadi pedoman hidup remaja. ${ }^{69}$ Melalui pemahaman Alkitab yang berdampak pada pertumbuhan iman peserta didik, dapat menjadikan firman Tuhan sebagai pedoman hidupnya dalam pertumbuhan iman maupun usahanya untuk meraih cita-citanya. Karena Allah menyatakan seluruh kehendakNya kepada peserta didik melalui Alkitab. "Maka setiap orang Kristen wajib berusaha membaca seluruh Alkitab dalam waktu tertentu."70 Alkitab harus dipahami untuk menjadikannya sebagai pedoman kehidupan orang Kristen termasuk remaja Kristen. Sebab Alkitab merupakan satusatunya pedoman bagi umat Allah termasuk remaja untuk menjadi "garam" dan "terang" dunia.

Dalam membaca Alkitab juga Tuhan berbicara kepada peserta didik dan menolongnya berkenalan lebih baik dengan Tuhan dan bersekutu lebih erat dengan-Nya. Oleh karena itu, para peserta didik wajib untuk pemahami Alkitab melalui tuntunan pembina iman peserta didik. Pembina harus mengajarkan kepada para peserta didik binaannya cara membaca Alkitab yang baik yakni: (1). Berdoa memohon pimpinan Tuhan; (2). Membaca bagian Alkitab dengan penuh perhatian; (3). Merenungkan Firman Tuhan yang dibaca dengan mengajukan pertanyaan, sebagai berikut: (a). Apa, (b). Mengapa, (c). Kapan, (d). Bagaimana, (e). Dimana, (f). Siapa; (4). Menggunakan buku-buku bantuan, seperti buku renungan harian dan (5). Berdoa, memohon pertolongan Tuhan untuk hidup sesuai dengan FirmanNya.

\subsubsection{Melalui Konseling.}

Guru Pendididikan Agama Kristen melalui bimbingan konseling pada prinsipnya bertujuan untuk membantu peserta didik mengenal bakat, minat dan potensinya agar berprestasi dalam pendidikan pilihannya untuk meraih cita-citanya. Selain itu tujuan bimbingan konseling juga untuk membina dan membimbing para peserta didik binaan pergaulannya agar tetap hidup dalam komunitas dan persekutuan Kristen agar bertumbuh imannya kepada Allah

\footnotetext{
${ }^{69}$ HL. Senduk, Pelayanan Tuhan, (TTP: Seksi Penerbit Yayasan Bethel, TTH), hlm. 93

${ }^{69}$ R. J. Porter MA, Katekisasi Masa kini, (TTP: Seksi Penerbita Yayasan Bethel, TTH), hlm. 93

70 Ibid, hlm. 31
} 
di dalam Tuhan Yesus Kristus. Hal terpenting bagi guru Pendididikan Agama Kristen dalam pelayanan bimbingan konseling adalah agar para peserta didik mengalami pertumbuhan dan perkembangan iman kearah kedewasaan dalam Tuhan Yesus Kristus.

John M. Nainggolan menyatakan bahwa; Bimbingan dan konseling oleh guru PAK di sekolah bertujuan untuk mewujudkan peserta didik, bahwa dirinya adalah manusia yang tidak terlepas dari ancaman hukuman maut (Roma. 6:23), ia juga menyadari bahwa dirinya membutuhkan seorang penyelamat yang mampu membebaskan dari hukuman maut (Lukas 19:10), dan pada akhirnya peserta didik tiba diperjumpaanya dengan Tuhan sang pembimbing agung. ${ }^{71}$ Bimbingan konseling guru Pendididikan Agama Kristen untuk mengajarkan kepada para peserta didik, bahwa dirinya adalah orang berdosa (Roma 3:23; 6:23) yang membutuhkan karya penyelamatan dari Tuhan Yesus Kristus yang adalah satu-satunya Juruselamat jalan ke Sorga (Yohanes 14:6). Hanya Yesus Kristus yang sanggup menyelamatkan para peserta didik dari hukuman dosa dan kematian kekal, untuk itu harus menerima Yesus Kristus menjadi Tuhan dan juruselamat pribadinya (Yohanes 1:12).

H. Prayitno dan Erman Amti menyatakan bahwa; Pelayanan bimbingan dan konseling di sekolah adalah pelayanan untuk semua murid yang mengacu pada keseluruhan perkembangan remaja. Pelayanan bimbingan dan konseling di sekolah sebenarnya telah dirintis sejak tahun 1960-an. ${ }^{72}$ Pelayanan bimbingan konseling bagi peserta didik merupakan proses pemberian bantuan secara terus menerus supaya remaja memahami dan sanggup mengarahkan diri agar memiliki karakter Yesus Kristus dalam kehidupannya.

Dasar pelayanan bimbingan konseling guru Pendididikan Agama Kristen bagi para remaja Kristen binaannya adalah Alkitab, karena itu guru Pendididikan Agama Kristen mempunyai hubungan pribadi yang harmonis dengan Tuhan sebagai teladan bagi para peserta didik binaannya. Implikasinya nyata dari pelayanan bimbingan konseling dari guru Pendididikan Agama Kristen kepada para peserta didik binaan adalah guru Pendididikan Agama Kristen harus menyediakan waktu, tidak hanya saat bimbingan tetapi sebagai penerapan firman Tuhan di dalam hidupnya untuk diteladani para peserta didik.

Dalam pelayanan bimbingan konseling, seorang guru Pendididikan Agama Kristen butuh pendekatan-pendekatan. Sofyan S. Willis mengatakan; "Pendekatan konseling (counseling approach) disebut juga teori konseling

${ }^{71}$ John M. Nainggolan, menjadi guru Agama Kristen, (Bandung : Generasi info Media, 2006), hlm. 92

72 H. Prayitno dan Erman Amti, Dasar-dasar Bimbingan dan Konseling, (Jakarta: Rineka Cipta, 2004), hlm. 29 
merupakan dasar bagi suatu praktek konseling. ${ }^{73}$ Guru Pendididikan Agama Kristen dalam pelayanan bimbingan konseling bagi para peserta didik membutuhkan pendekatan-pendekatan untuk memudahkan dalam mencapai tujuan pelayanannya.

Anthony Yeo menyatakan bahwa; Pendekatan konseling tujuannya adalah membantu remaja yang memiliki masalah, meskipun hal itu di jalankan dengan satu cara di mana perhatian lebih-lebih diberikan kepada pribadi orang itu beserta hidup relasionalnya daripada terhadap masalahnya sendiri. ${ }^{74}$ Dalam pendekatan konseling ini bagi peserta didik memungkinkan guru Pendididikan Agama Kristen untuk melihat masalah-masalah dengan pandangan yang positif dan memandang peserta didik sebagai orang-orang yang berpotensi untuk dikembangkan bagi kemuliaan Tuhan lewat pelayanan Tuhan. Jadi berbagai problema yang dihadapi peserta didik juga dapat memperlihatkan fungsi perlindungan karena adanya suatu pendekatan konseling bagi peserta didik.

Pendekatan bimbingan dan konseling bagi peserta didik, salah satunya ialah guru Pendididikan Agama Kristen memberikan perhatian agar para peserta didik mempunyai kesempatan untuk berbicara dan mengeluarkan isi hatinya tanpa suatu tekan tertentu. Jadi guru Pendididikan Agama Kristen hanya memberikan perhatian, secara aktif terlibat dalam proses membantu peserta didik untuk memusatkan perhatian pada masalahmasalahnya dan mencari jalan keluar. Jikalau guru Pendididikan Agama Kristen bersedia untuk mengetahui hal-hal yang di alami oleh peserta didik untuk mampu menasihati, memotivasi, memfasilitas remaja untuk bertindak keluar dari masalah hidupnya sesuai dengan cara Tuhan Yesus. Namun jika guru Pendididikan Agama Kristen kurang dekat kepada peserta didik, maka tidak mungkin menerima pendapat atau nasihat dari pembina rohaninya. Dengan demikian, maka perlu adanya upaya guru Pendididikan Agama Kristen membangun relasi dan komunikasi yang baik dan harmonis sehinga peserta didik dapat menerima pembina rohaninya.

Penekanan dalam pendekatan bimbingan dan konseling adalah membantu peserta didik untuk membangun hubungannya dengan Tuhan Yesus secara benar dan harmonis dan mampu menangani masalah-masalah hidup dengan penuh percaya diri, sebagai bukti kedewasaan iman kepada Allah did alam Tuhan Yesus Kristus.

\section{Referensi}

Tim penyusun KBBI, Jakarta: Balai Pustaka, 2002.

\footnotetext{
${ }^{73}$ Sofyan S. Willis, Konseling Individual Teori dan Pratek, (Bandung: ALFABETA, 2004), hlm. 55

${ }^{74}$ Anthony Yeo, Konseling Suatu Pendekatan Masalah, (Jakarta: BPK Gunung Mulia, 2001). Hlm. 15
} 
Singgih D. Gunarsa, dan Y. Singgih D. Gunarsa, Psikologi untuk Membimbing, Jakarta: BPK Gunung Mulia 2007

Prayitno, dan Erman Amti, DAsar-dasar Bimbingan dan Konseling, Jakarta:

Rineka Cipta, 2004

Hodari Nawawi, Administrasi dan Organisasi Bimbingan dan Penyuluhan, Pontianak: Grahlia Indonesia, 1986

Soejipto, dan Raflis Kosasi, Profesi Keguruan, Jakarta: Rineka Cipta, 1999

Slameto, Belajar dan Faktor-faktor yang Mempengaruhinya, Jakarta: Rineka Cipta, 2003

Moh. Uzer Usman, Menjadi Guru Profesional, Bandung: PT. Remaja Rosdakarya, 2008

Stephen Tong, Arsitek Jiwa II, Surabaya: Momentum, 2008

Thoifuri, Menjadi Guru Inisiator, Semarang: Rasail Media Group, 2008

B. S. Sidjabat, Menjadi Guru Profesional: Sebuah Perspektif Kristiani, Bandung: Yayasan Kalam Hidup, 2000

E. Mulyasa, menjadi guru profesional, menciptakan pembelajaran kreatif dan menyenangkan, Bandung: Remaja rosdakarya, 2008

Syaiful Bahri Djamarah, Guru dan Nara didik, Jakarta: Rineka, 2000

S. Nasution, Didaktik asas-asas mengajar, Jakarta: Bumi Aksara, 2000

Denis Green, Pengenalan Perjanjian Lama, Malang Jatim: Gandum Mas, 1984

Tulus. TU.U, Dasar konseling Pastoral, Yogyakarta: Andi Ofset, 1987

Noordegraf, Orientasi diakonal Gereja, Jakarta: BPK, t.th

Mary Go Setiawni, Pembaruan Mengajar, Jakarta: BPK Gunung Mulia, 2005

Bruce Millne, Mengenali Kebenaran, Jakarta: Gunung Mulia, 2002

Stephen Tong, Seni Membentuk Karakter, Jakarta: Momentum, 2005

Belandia. Non - Serona, Profesionalisme Guru dan Bingkai Materi, Bandung: Bina Media Informasi, 2004

W.A. Henrichsen, Cara Melatih Murid Kristus, Bandung: Yayasan Kalam Hidup, 1994

Brian J. Bailey, Pilar-Pilar Iman, Jakarta: Voice Of Hope, 2005

Derek Prince, Foundations For Righteous Living, Jakarta: Derek Prince Ministries Indonesia, 2005

Billy Joe Daugherty, Kuasa Iman, Jakarta: Yayasan Kalam Hidup, 2004

Antony A. Hoekema, Diselamatkan Oleh Anugerah, Surabaya: Momentum, 2006

Tim Penyusun, Ensiklopedi Alkitab Masa Kini Jilid I, Jakarta: Yayasan Komunikasi Bina Kasih, 1992

Derek Prince, Iman Yang Olehnya Kita Hidup, Jakarta: Derek Prince Ministries Indonesia, 2005

Ronald Dunn, Krisis Iman, Malang: Gandung Mas, 1997

Henk ten Napel, Jalan yang Lebih Utama Lagi, Jakarta: BPK Gunung Mulia, 2001

W. S. Winkel dan M. M. Sri Hastuti, Bimbingan dan konseling, (ogyakarta: Media abadi, 2004

Singgih D. Gunarsa dan Y. Singgih D. Gunarsa, Psikologi untuk membimbing, Jakarta: BPK Gunung Mulia, 2007

Leroy Eims, doa bukan sedar kata-kata, Jakarta: Gandum Mas, 1982

Bruce Milne, mengenalin kebenaran, Jakarta: BPK Gunung Mulia, 2003 
Ruth. F. Selan, Pedoman pembinaan warga jemaat, Bandung: Yayasan Kalam Hidup, 2006

Mangara Sinamo, Kumpulan ilustrasi penggugah inspirasi, Jakarta: Cv. Le Peridien, 2007

Stephen Tong, Peta dan Teladan Allah, Jakarta: Lembaga Reformed Injili Indonesia, 1994

Paulus Lilik Kristianto, Prinsip dan Pratik Pendidikan Agama Kristen, Yogyakarta: ANDI, 2006

Rick Osborne, Cara Mengajar Anak-anak Berdoa, Batam: centre, Gospel Press, 2002

Charlie Riggs, Belajar berjalan dengan Allah, Jakarta: Persekutuan Pembaca Alkitab, 2005

H.L. Senduk, Pelayanan Tuhan, TTP: Seksi Penerbit Yayasan Bethel, TTH

R. J. Porter MA, Katekisasi Masa kini, TTP: Seksi Penerbita Yayasan Bethel, TTH

John M. Nainggolan, menjadi guru Agama Kristen, Bandung : Generasi info Media, 2006

H. Prayitno dan Erman Amti, Dasar-dasar Bimbingan dan Konseling, Jakarta: Rineka Cipta, 2004

Sofyan S. Willis, Konseling Individual Teori dan Pratek, Bandung: ALFABETA, 2004.

Anthony Yeo, Konseling Suatu Pendekatan Masalah, Jakarta: BPK Gunung Mulia, 2001. 